\title{
CRADA Final Report - Non-Contact Ultrasonic Drying Technology for Drying Owens Corning Dry-Use Fiberglass
}

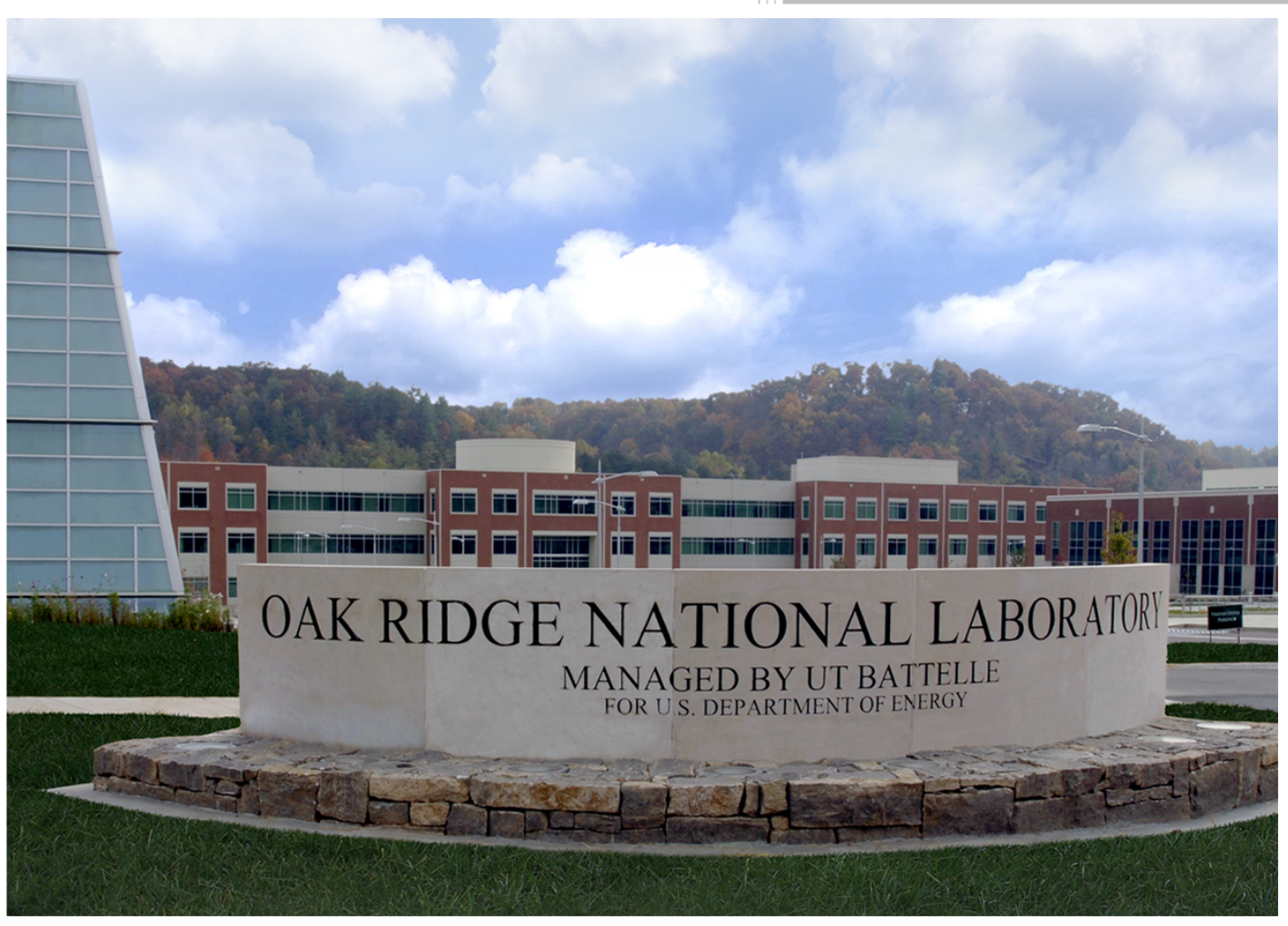

CRADA final report for CRADA number NFE-18-07270

Approved for public release. Distribution is unlimited.
Viral K. Patel

Donald Scarsella

Danilo Luchesi

Brandon Vaughn

Eric Vickery

June 2019 


\section{DOCUMENT AVAILABILITY}

Reports produced after January 1, 1996, are generally available free via US Department of Energy (DOE) SciTech Connect.

Website http://www.osti.gov/scitech/

Reports produced before January 1, 1996, may be purchased by members of the public from the following source:

National Technical Information Service

5285 Port Royal Road

Springfield, VA 22161

Telephone 703-605-6000 (1-800-553-6847)

TDD 703-487-4639

Fax 703-605-6900

E-mail info@ntis.gov

Website http://www.ntis.gov/help/ordermethods.aspx

Reports are available to DOE employees, DOE contractors, Energy Technology Data Exchange representatives, and International Nuclear Information System representatives from the following source:

Office of Scientific and Technical Information

PO Box 62

Oak Ridge, TN 37831

Telephone 865-576-8401

Fax 865-576-5728

E-mail reports@osti.gov

Website http://www.osti.gov/contact.html

This report was prepared as an account of work sponsored by an agency of the United States Government. Neither the United States Government nor any agency thereof, nor any of their employees, makes any warranty, express or implied, or assumes any legal liability or responsibility for the accuracy, completeness, or usefulness of any information, apparatus, product, or process disclosed, or represents that its use would not infringe privately owned rights. Reference herein to any specific commercial product, process, or service by trade name, trademark, manufacturer, or otherwise, does not necessarily constitute or imply its endorsement, recommendation, or favoring by the United States Government or any agency thereof. The views and opinions of authors expressed herein do not necessarily state or reflect those of the United States Government or any agency thereof. 
ORNL/TM-2019/1156

CRADA/NFE-18-07270

Energy and Transportation Science Division

\title{
CRADA FINAL REPORT - NON-CONTACT ULTRASONIC DRYING TECHNOLOGY FOR DRYING OWENS CORNING DRY-USE FIBERGLASS
}

Viral K. Patel (Building Equipment Research Group, ORNL) Donald Scarsella (Energy Program Manager, Owens Corning) Danilo Luchesi (Corporate Energy Engineer, Owens Corning)

Brandon Vaughn (Sr. Technical Product Lead, Owens Corning)

Eric Vickery (Technical Product Lead, Owens Corning)

Date Published: June 2019

\author{
Prepared by \\ OAK RIDGE NATIONAL LABORATORY \\ Oak Ridge, Tennessee 37831-6283 \\ managed by \\ UT-BATTELLE, LLC \\ for the \\ US DEPARTMENT OF ENERGY \\ under contract DE-AC05-00OR22725
}




\section{CONTENTS}

CONTENTS

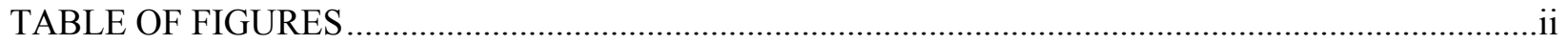

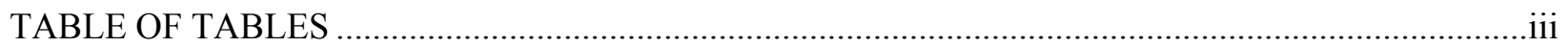

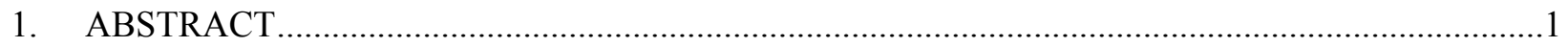

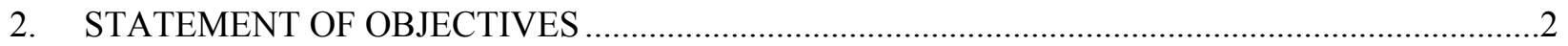

3. BENEFITS TO DOE ADDITIVE MANUFACTURING OFFICE MISSION ..................................2

4. TECHNICAL DISCUSSION OF WORK PERFORMED BY ALL PARTIES .................................

4.1 DESIGN AND FABRICATION OF EXPERIMENTAL SETUP FOR NON-CONTACT

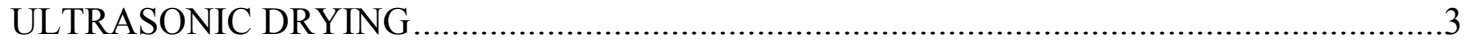

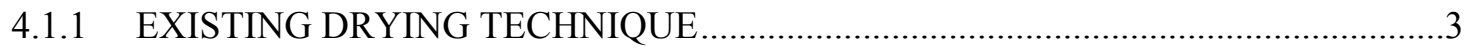

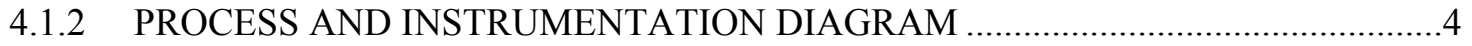

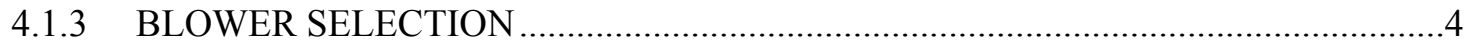

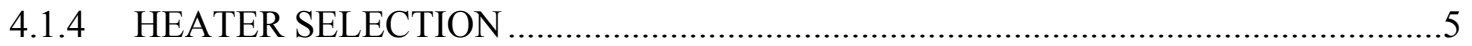

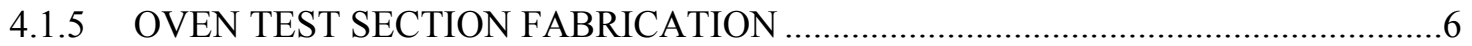

4.1.6 ULTRASONIC TRANSDUCER AND AMPLIFIER SELECTION ..........................

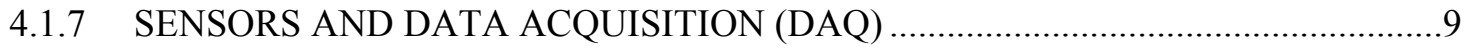

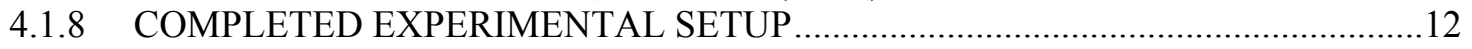

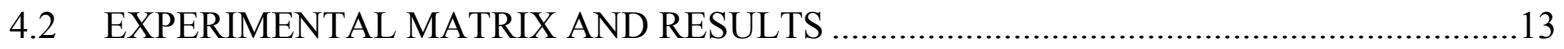

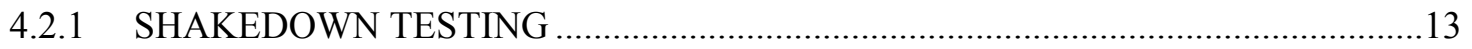

4.2.2 PROPOSED EXPERIMENT MATRIX AND PROCEDURE .....................................15

4.2.3 EXPERIMENTAL RESULTS AND DISCUSSION …..........................................16

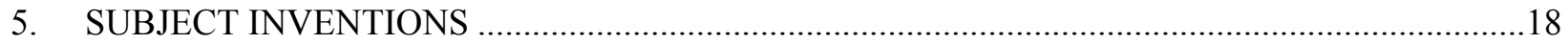

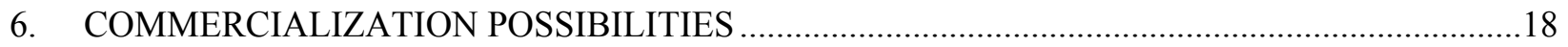

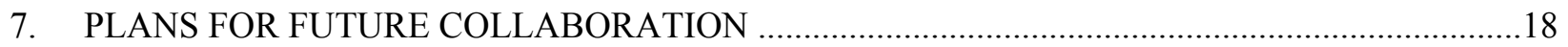

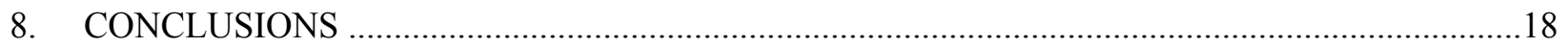




\section{TABLE OF FIGURES}

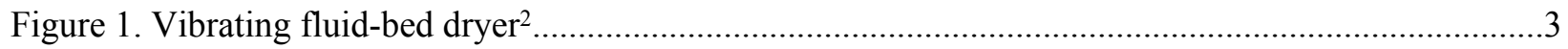

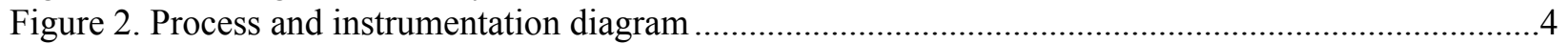

Figure 3. (a.) Commercially available blower selected for fluidized bed oven setup and (b.) blower

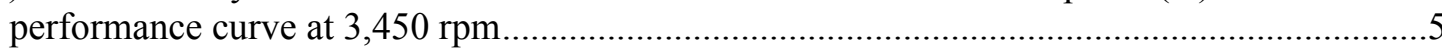

Figure 4. Completed heater assembly showing inlet and outlet plenums (air flow from left to right) ..........6

Figure 5. (a.) Heater duct section showing heating elements and ceramic supports and (b.) electrical box for heater on/off control

Figure 6. Fluidized bed oven test section showing air flow path (red arrows), sensor locations and other components

Figure 7. (a.) Bolt-clamped Langevin transducer attached to side wall of oven test section and (b.) position of transducer on inside wall of oven test section (perforated plate is intentionally covered for proprietary reasons)

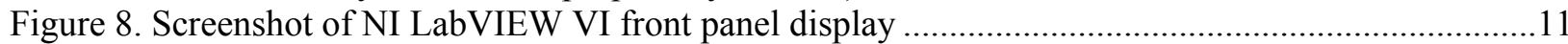

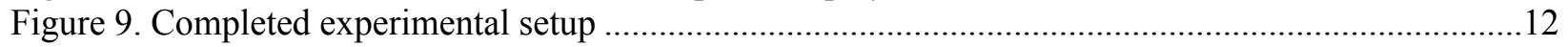

Figure 10. Test stand for shakedown testing of different duct diameters with perforated plate.................13

Figure 11. Shakedown test results with different duct diameter outlets - temperatures at inlet, heater

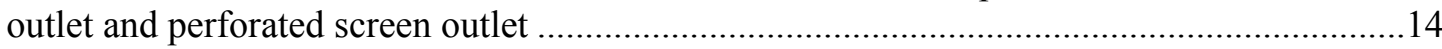

Figure 12. Shakedown test results with different duct diameter outlets - air flow rate and static pressure 


\section{TABLE OF TABLES}

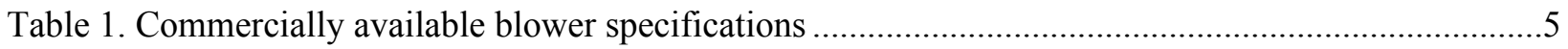

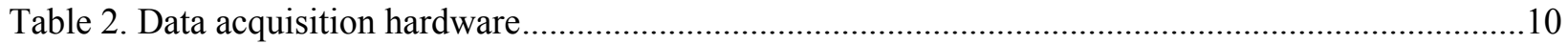

Table 3. Measured values of heater applied voltage and current .............................................................12

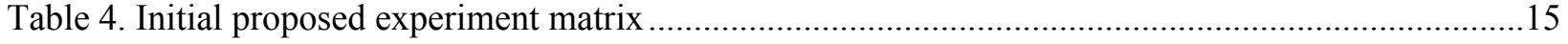

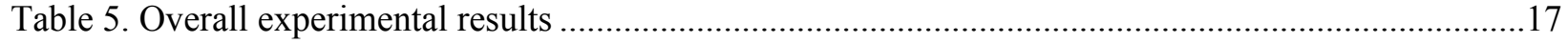




\section{ABSTRACT}

In this collaborative research project between ORNL and the Composites Division of Owens Corning (a world leader in the production of glass-fiber reinforcement materials), non-contact ultrasonic drying was studied as a way to enhance the drying of Dry-Use Fiberglass Products. Current methods of drying fiberglass products utilize traditional convection ovens with relatively low efficiency. Enhancing the drying process through the use of different techniques is highly desirable to reduce the overall energy consumption attributed to drying.

The research was based on similar technology previously developed by ORNL for clothes drying applications called direct-contact ultrasonic drying, ${ }^{1}$, where wet fabric was placed in contact with piezoelectric transducers which vibrated at high frequency. The high frequency vibration was used to atomize liquid water trapped within the fabric and resulted in mechanical extraction of the moisture, with significant improvement in energy efficiency compared to conventional drying technology. Based on this past success, non-contact ultrasonic drying was proposed for this project. Researchers from Owens Corning and ORNL designed and fabricated a benchtop fluidized bed oven setup at ORNL to experimentally study the effect of non-contact ultrasonic vibration on traditional convective hot air drying. Conditions similar to large scale drying ovens were achieved in the benchtop experimental setup and drying experiments were conducted on fiberglass samples provided by Owens Corning. The experimental results showed that up to $7.21 \%$ enhancement in the water removal rate was possible due to non-contact ultrasonic vibration. The results are encouraging for future developments in energy-efficient drying technology for all kinds of industrial applications.

\footnotetext{
${ }^{1}$ Momen, A. M., Gluesenkamp, K. R., Vineyard, E. A., Kisner, R. A., 2016, Patent, Dryer Using High Frequency
} Vibration, WIPO, Publication number WO/2016/182832, Application number PCT/US2016/030885. 


\section{STATEMENT OF OBJECTIVES}

The objective of this research work was to gauge the feasibility of using non-contact ultrasonic drying technology for drying Owens Corning Dry-Use products. The ORNL researchers were to quantify the benefits of non-contact ultrasonic drying in Fiberglass manufacturing process by applying a combination of hot-air and ultrasonic techniques. Owens Corning would send down some product samples to conduct quick trials at ORNL and then conduct further research work at their own facility. The high-level project plan and objectives were:

1. Non-Disclosure and Material Transfer Agreements between ORNL and Owens Corning.

2. Owens Corning team sends composites sample material to ORNL for evaluation

3. ORNL and Owens Corning team develops pilot test set-up at ORNL to conduct quick trials

4. ORNL team modifies the test setup design to improve the performance of non-contact ultrasonic drying process on Owens Corning product(s).

5. ORNL team conducts comprehensive testing and evaluation on Owens Corning product(s).

6. ORNL team presents research outcomes to Owens Corning and receive feedback from OC team members.

7. ORNL team proposes next steps for conducting trials at the Owens Corning facility.

8. ORNL and Owens Corning will deliver a final report to DOE.

\section{BENEFITS TO DOE ADDITIVE MANUFACTURING OFFICE MISSION}

Owens Corning is a Better Plants partner and signed a voluntary pledge with DOE to reduce its energy intensity by $25 \%$ in 10 years. This goal was achieved at the end of 2017. Developing and implementing new technologies similar to non-contact ultrasonic drying would help them in achieving further energy efficiency gains. This work supports the mission of AMO to catalyze research, development and adoption of energy-related advanced manufacturing technologies and practices to drive U.S. economic competitiveness and energy productivity. In particular, this research aligns with the strategic performance goals of improving the productivity and energy efficiency of U.S. Manufacturing and transitioning DOE supported innovative technologies and practices into U.S. manufacturing capabilities. 


\section{TECHNICAL DISCUSSION OF WORK PERFORMED BY ALL PARTIES}

\subsection{DESIGN AND FABRICATION OF EXPERIMENTAL SETUP FOR NON-CONTACT ULTRASONIC DRYING}

\subsubsection{EXISTING DRYING TECHNIQUE}

The existing drying technique for dry-use fiberglass involves the use of fluidized bed ovens ${ }^{2}$, which are typically used for drying wet powders, granules, pellets and other bulk solids. A natural gas burner is generally used to heat up ambient air to high temperature. The hot air is then directed into the oven through a perforated air distributor. The material to be dried is fed into the oven onto the distributor where it interacts with upward moving hot air. Convective drying occurs and the dried final product is removed from the oven. There are two types of rectangular fluid-bed dryers - static and vibrating. A schematic of a vibrating fluid-bed dryer is shown below in Figure 1.

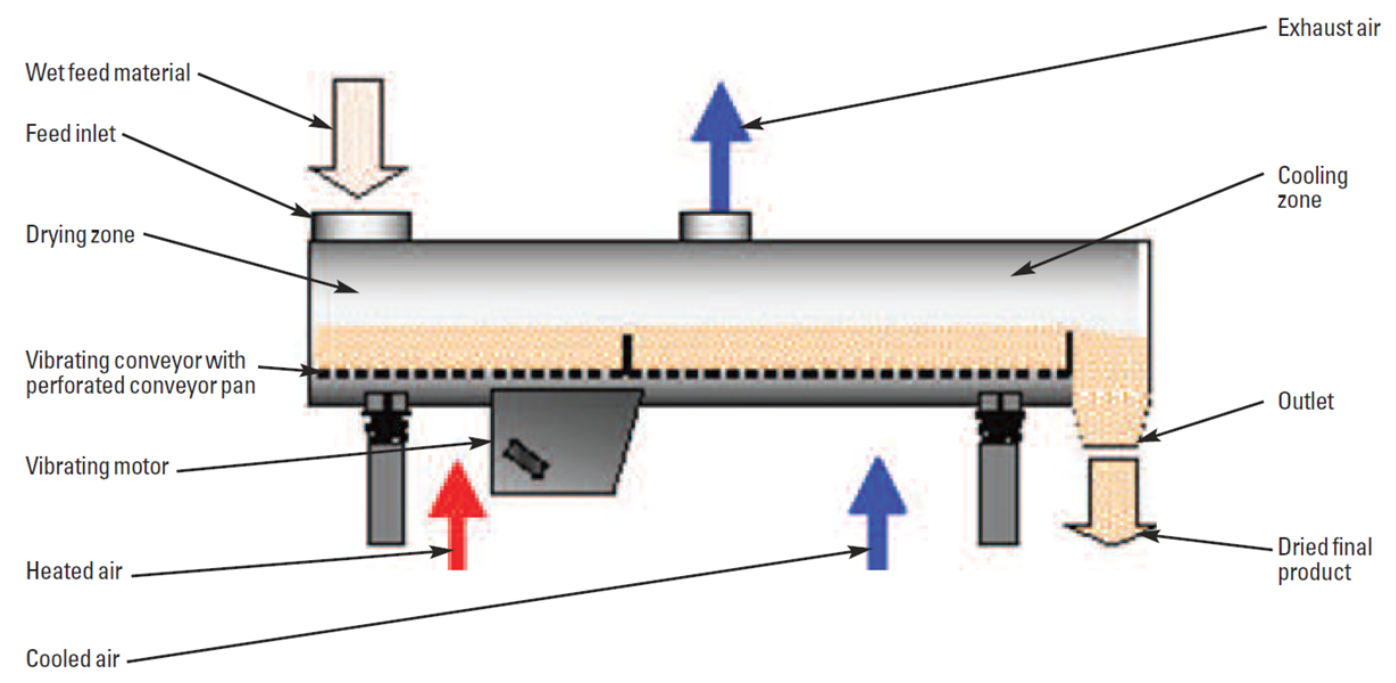

Figure 1. Vibrating fluid-bed dryer ${ }^{2}$

As shown above, in a vibrating oven, the continuous agitation of the feed material causes it to be transported along the length of the oven towards the outlet. The selection of static vs. vibrating dryer is made based on different factors such as material size, required material retention time, operating temperature, process control etc.

To inform the experimental design for the current work, engineering specifications from the existing drying ovens were used. The large-scale ovens typically have a high throughput and have multiple zones. Since it was impractical to modify the existing oven to investigate the effect of non-contact ultrasonic drying, a scaled-down benchtop experimental setup was designed and fabricated at ORNL. The typical air temperatures, flow rate and static pressure in the different zones of the large-scale oven were used to determine the operating requirements for the scaled-down benchtop oven. Available heaters and blowers fixed the maximum possible capacity and air flow rate for the benchtop oven. These were used to determine the largest size of the test section for the oven that could be used while still meeting the temperature and air flow requirements.

\footnotetext{
${ }^{2}$ Randel, E., Schak, J., Islam, A., April 2013, “Fluid-bed dryers: static vs. vibrating,” www.powederbulk.com
} 


\subsubsection{PROCESS AND INSTRUMENTATION DIAGRAM}

The process and instrumentation diagram for the experimental setup is shown below in Figure 2. The main components are the blower, heater section and oven.

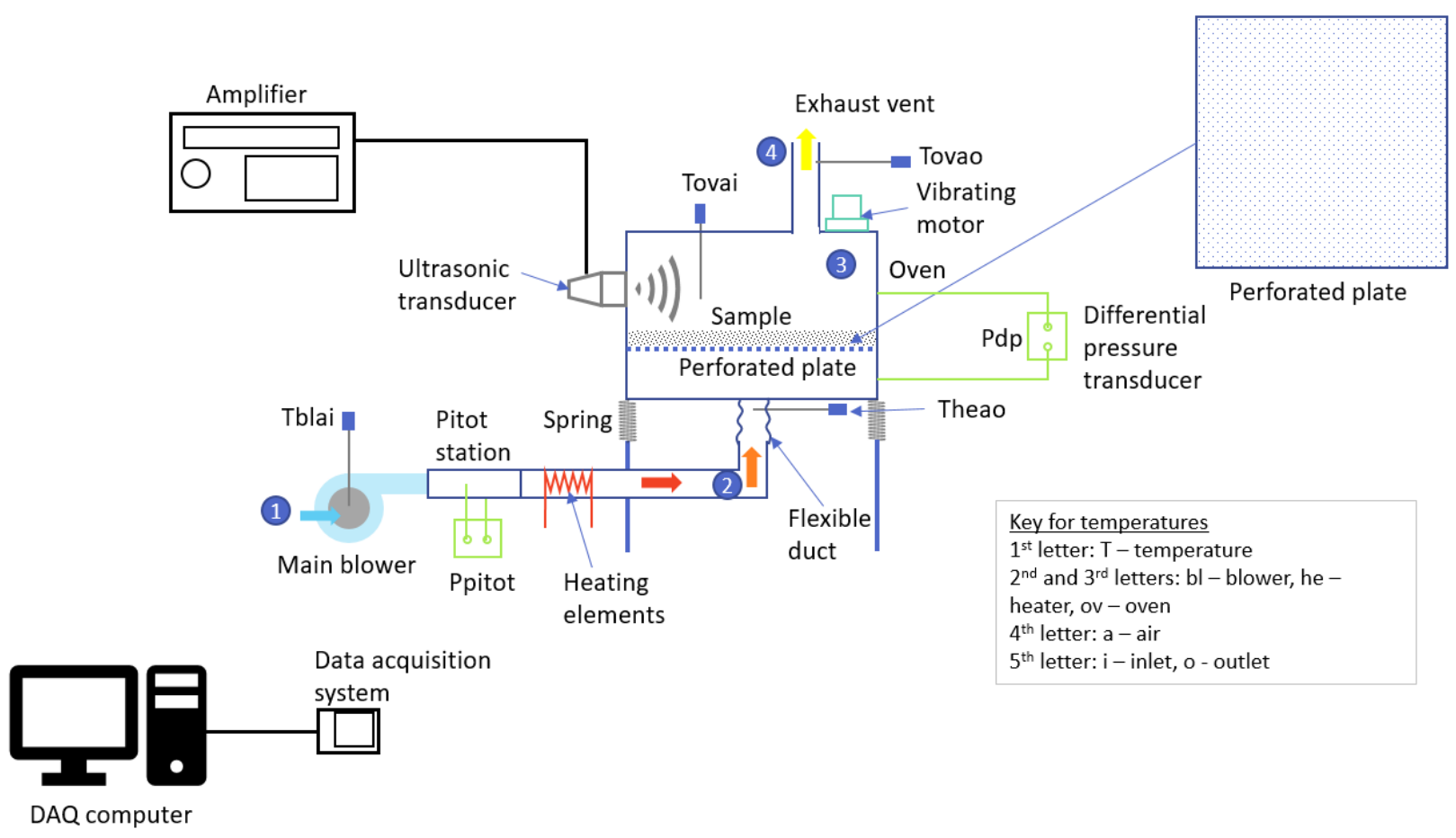

Figure 2. Process and instrumentation diagram

As shown above, ambient air is first drawn into the blower at state point (1). It then enters the traversing pitot station. The static and dynamic pressure are measured in the pitot station using a differential pressure transducer. This is used to determine the volumetric air flow rate. Using the upstream ambient temperature, the air density can be found and used with the volumetric air flow rate to determine the mass flow rate. The ambient air then enters the heater section (described further in Section 4.1.4) where it is heated to high temperature. The air leaves the heater section at state point (2) and enters the oven test section through a flexible duct. After entering the oven, the air passes through a perforated distributor plate and interacts with the material to be dried, at state point (3). The air then leaves the oven through the exhaust vent at state point (4). The installation of the ultrasonic transducer and other sensors is described in the sections that follow.

\subsubsection{BLOWER SELECTION}

A commercially available blower was used in the experimental setup with the following characteristics: 
Table 1. Commercially available blower specifications

\begin{tabular}{|l|l|}
\hline Airflow at static pressure & $250 \mathrm{CFM}$ at 3 in. H2O \\
\hline Drive type & Direct \\
\hline Motor speed & $3,450 \mathrm{rpm}$ \\
\hline Power & $1 / 2 \mathrm{hp}$ \\
\hline Outlet diameter and shape & 4 ", round \\
\hline Inlet diameter and shape & 4 ", round \\
\hline Voltage & $120 / 230 \mathrm{~V} \mathrm{AC}$ \\
\hline Current & $7.2 / 3.6 \mathrm{~A}$ \\
\hline Temperature range & 0 to $100^{\circ} \mathrm{F}$ \\
\hline
\end{tabular}

A photo of the blower and its performance curve are shown in Figure $3 a$ and $b$, respectively. Based on the initial engineering design calculations, the blower was more than capable of providing the minimum flow necessary for the fluidized bed oven setup.

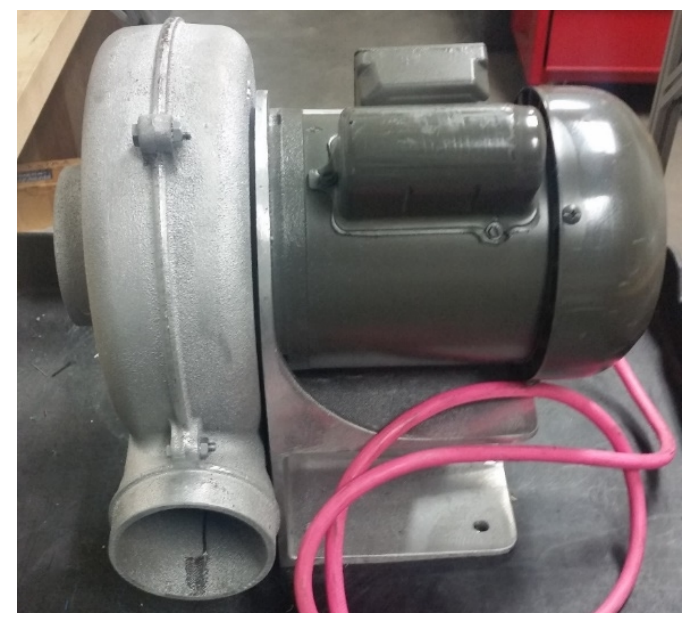

(a.)

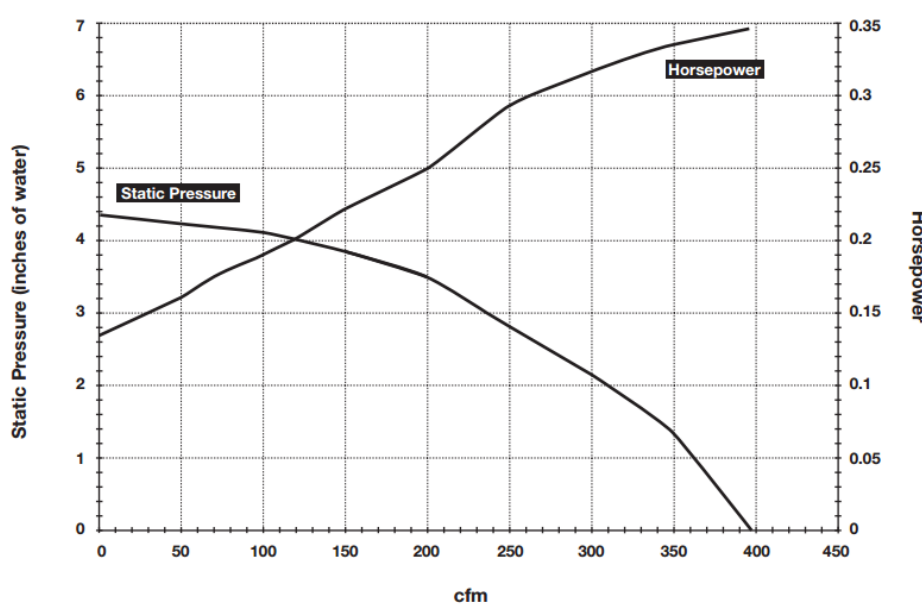

(b.)

Figure 3. (a.) Commercially available blower selected for fluidized bed oven setup and (b.) blower performance curve at $3,450 \mathrm{rpm}$

\subsubsection{HEATER SELECTION}

The heaters necessary to achieve the design temperatures in the test section were sourced from previous experimental setups. They were flow-through electric resistance heaters with heating elements and two heaters of similar capacity $(\sim 4 \mathrm{~kW})$ were used in parallel. Inlet and outlet plenums were fabricated out of sheetmetal as shown in Figure 4. The inside of the heater duct section which held the heating elements is shown in Figure 5a. The heaters could be activated individually or both at the same time using the electrical box shown in Figure $5 \mathrm{~b}$. 


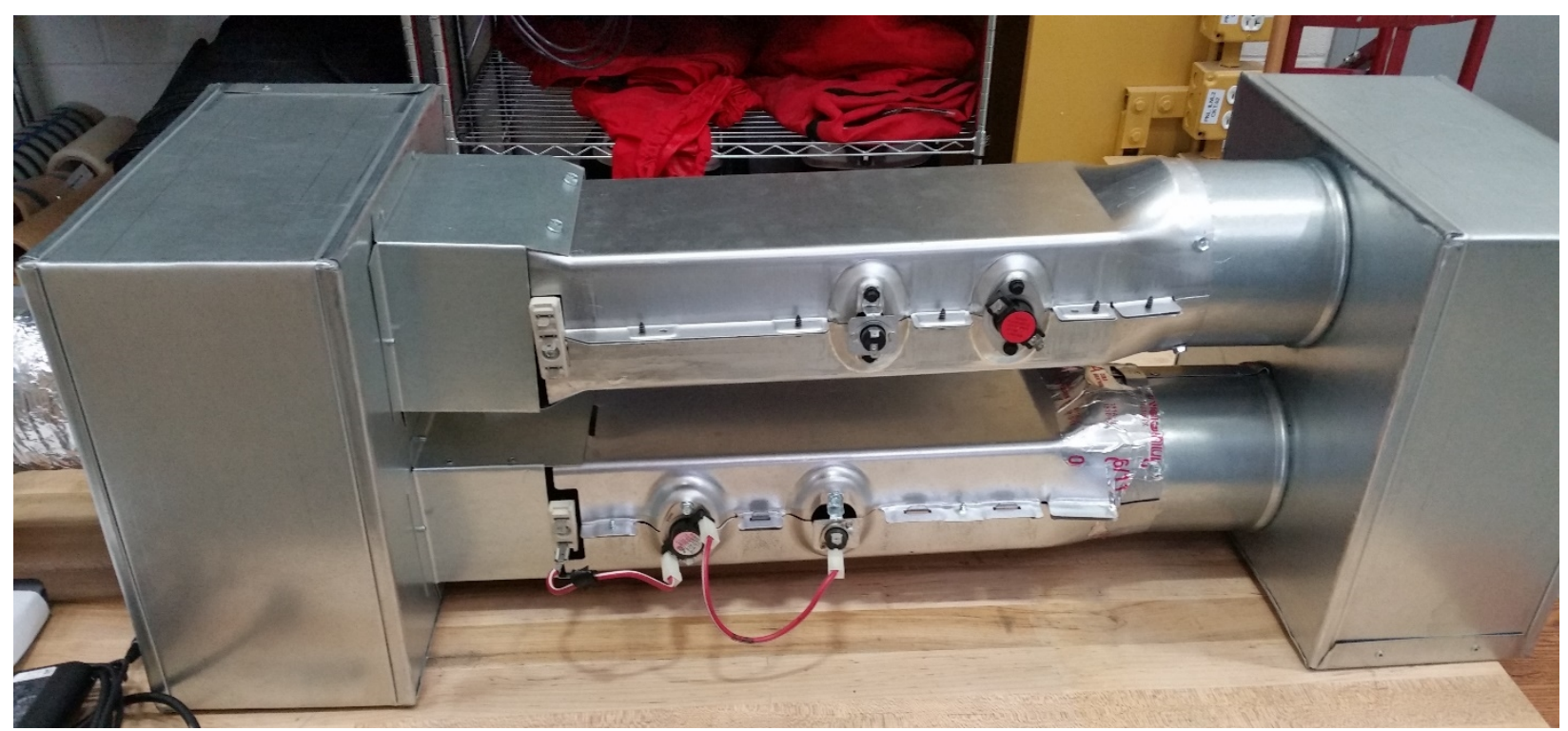

Figure 4. Completed heater assembly showing inlet and outlet plenums (air flow from left to right)

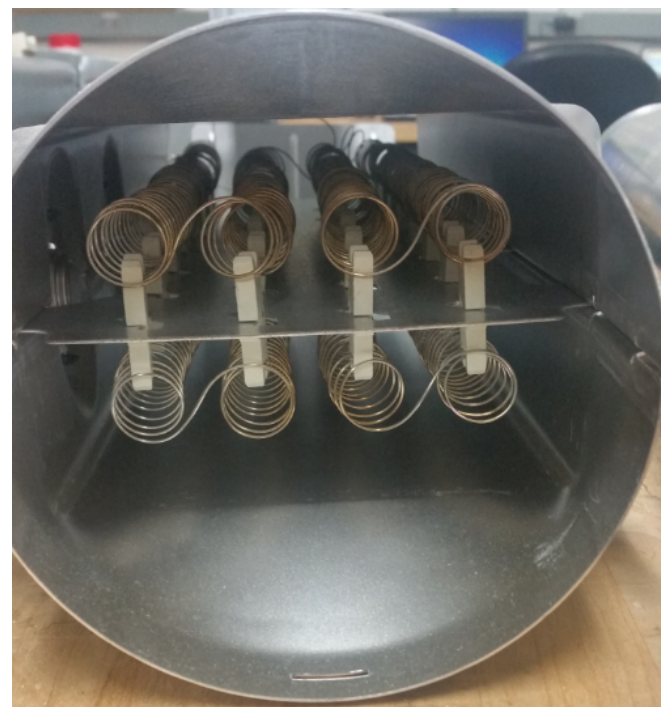

(a.)

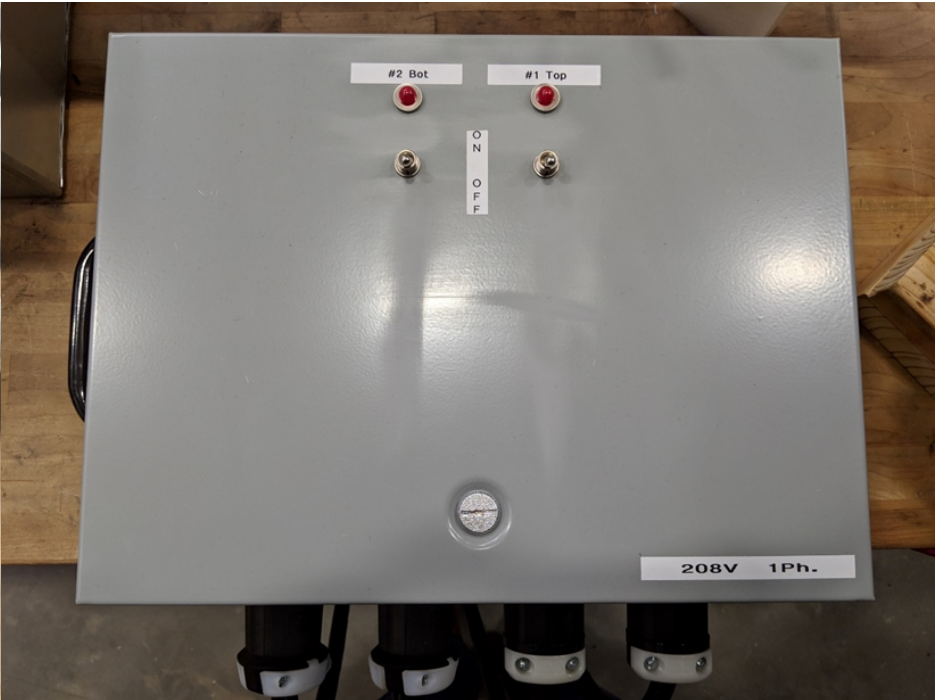

(b.)

Figure 5. (a.) Heater duct section showing heating elements and ceramic supports and (b.) electrical box for heater on/off control

\subsubsection{OVEN TEST SECTION FABRICATION}

The oven test section consisted of a sheetmetal box with an air inlet at the bottom and outlet at the top. The lid of the oven test section was removable to facilitate sample loading and unloading. A perforated plate was installed halfway between the top and bottom of the oven to distribute the air flow and enhance fluidization of the material bed. The sample material was loaded into the oven by placing it directly on top of the perforated plate. The perforation pattern of the plate was based on the large-scale oven designs. Figure 6 shows a photo of the completed oven test section (before insulation was applied), along with the air flow path and sensor locations. As illustrated by the red arrows in Figure 6, air flowed out of the heater section and vertically upward into the oven. The oven rested on four springs and was connected to the heater section with a flexible duct. This ensured that when the vibrating motor on the top of the oven was 
activated, the vibration was isolated to the oven test section only. The purpose of the vibration was to continuously agitate the material and ensure that it remained evenly distributed over the perforated plate.

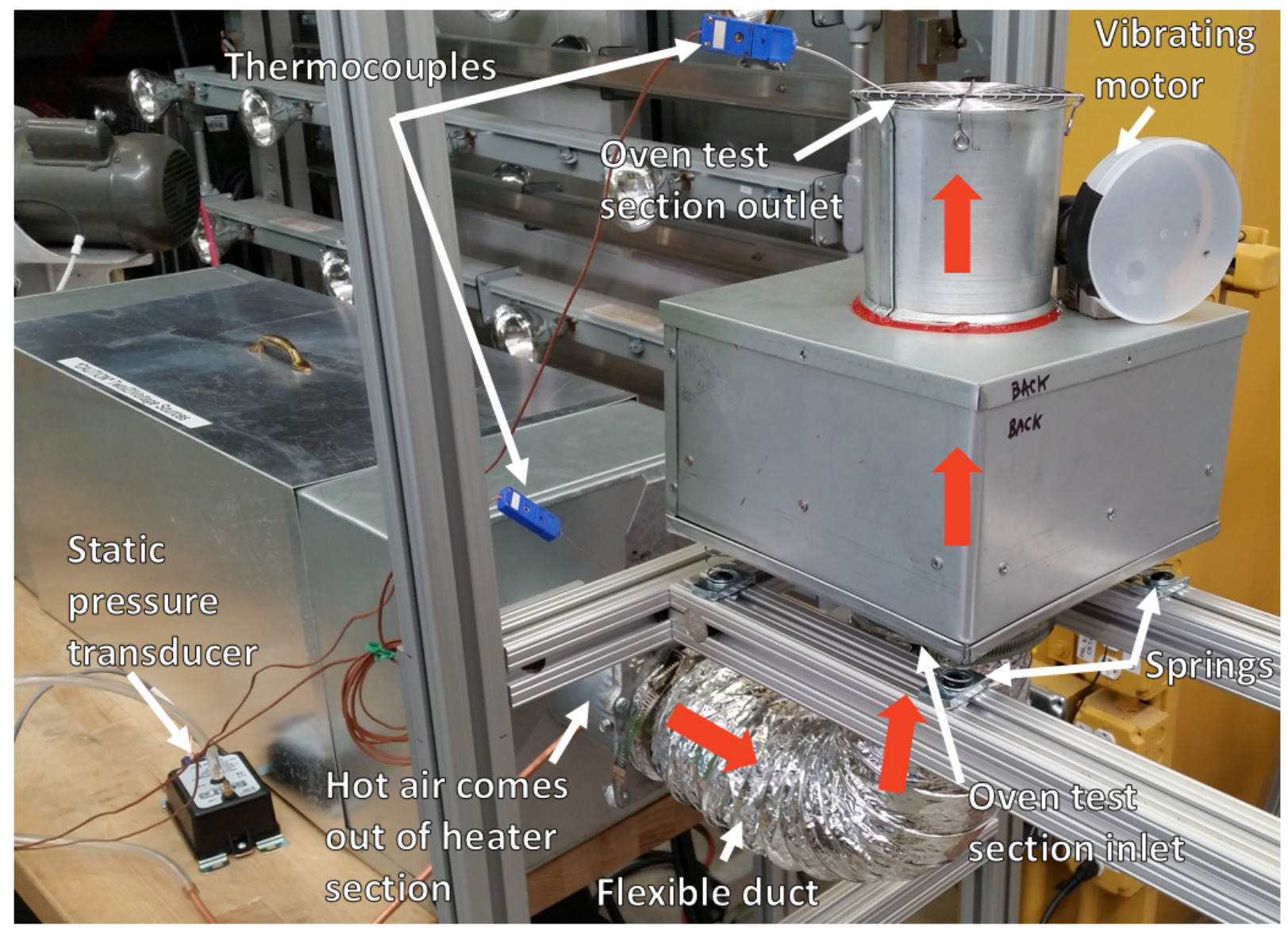

Figure 6. Fluidized bed oven test section showing air flow path (red arrows), sensor locations and other components

The physical size of the oven test section was determined by several factors and the following procedure was followed to size it:

1. Since the available heater capacity and target temperature in the oven test section were known, the minimum air flow rate necessary to achieve this was calculated.

2. Based on the air flow rate requirement and the blower fan curve, the system was assembled to deliver the air flow to the oven test section at the target temperature.

3. Since the pressure drop across the perforated plate section was a function of the plate crosssectional area, it was important to determine the functional relationship between these two quantities:

a. A larger area would result in a lower pressure drop, which would increase the air flow rate. This in turn would decrease the air temperature measured after the perforated plate.

b. On the other hand, a smaller area would result in a higher pressure drop, which would decrease the air flow rate. This in turn would increase the air temperature measured after 
the perforated plate. While this was desirable to meet the target temperature, too great an increase could also cause the heater temperature safety limits to be exceeded.

4. It was decided that tests would be conducted with perforated plates of different cross-sectional areas, with measurements of air flow rate and maximum temperature achieved.

5. Rather than purchasing multiple perforated plates, a single large plate was ordered, and the incoming duct area was varied by using transition pieces with increasing diameter.

6. Experiments were conducted to establish a relationship between duct area and air temperature before and after the perforated plate section (results are given in Section 4.2.1). These were used to determine the minimum cross-sectional area needed for the perforated plate for which the target temperature could be reached.

7. When the minimum area of the perforated plate was determined, the remainder of the oven test section was designed and fabricated around it.

\subsubsection{ULTRASONIC TRANSDUCER AND AMPLIFIER SELECTION}

For this project, direct-contact ultrasonic drying (where the material to be dried is always in contact with the ultrasonic transducers) was not used. Instead, non-contact ultrasonic drying was used, wherein the ultrasonic transducer enhanced or augmented conventional convective hot air drying in a fluidized bed oven. As a result, the selection of the ultrasonic transducer was determined by examining the literature for past work on hot air drying augmented by high-power ultrasound. In particular, the work of Garcia-Perez et $\mathrm{al}^{3}$ showed that a fluidized-bed drying chamber could be combined with an ultrasonic transducer to assist the hot air-drying process for moisture removal of foodstuff. The study combined modeling results with experiments. A bolt clamped Langevin transducer was used along with a mechanical amplifier. The transducer was attached to the wall of the drying chamber and a finite element model (FEM) was used to study the vibration modes of the cylindrical chamber. This enabled the transducer assembly and drying chamber to both be resonant, resulting in enhanced heat and mass transfer within the chamber.

Along these lines, a suitable bolt clamped Langevin transducer (BLT) was selected for this project and attached to the wall of the fluidized bed oven test section, as shown in Figure 7. BLTs consist of two piezoelectric ceramic rings which are sandwiched between two metal pieces (one made of aluminum and the other made of stainless steel). The aluminum piece has a conical shape which acts as a mechanical amplifier and this is the part of the transducer that is attached to the structure through which the generated ultrasonic waves propagate. The transducer assembly is clamped together through the central axis with a single bolt which has a pre-defined torque (and, therefore, clamping force). The transducer used in this work had a resonance frequency of $40 \mathrm{kHz}$ and maximum power rating which was similar to previous transducers used in other studies.

\footnotetext{
${ }^{3}$ J. V. Garcia-Perez, J. A. Carcel, S. de la Fuente-Blanco, E. Riera-Franco de Sarabia, 2006, "Ultrasonic drying of
} foodstuff in a fluidized bed: Parametric study," Ultrasonics, 44, pp. e539-e543. 


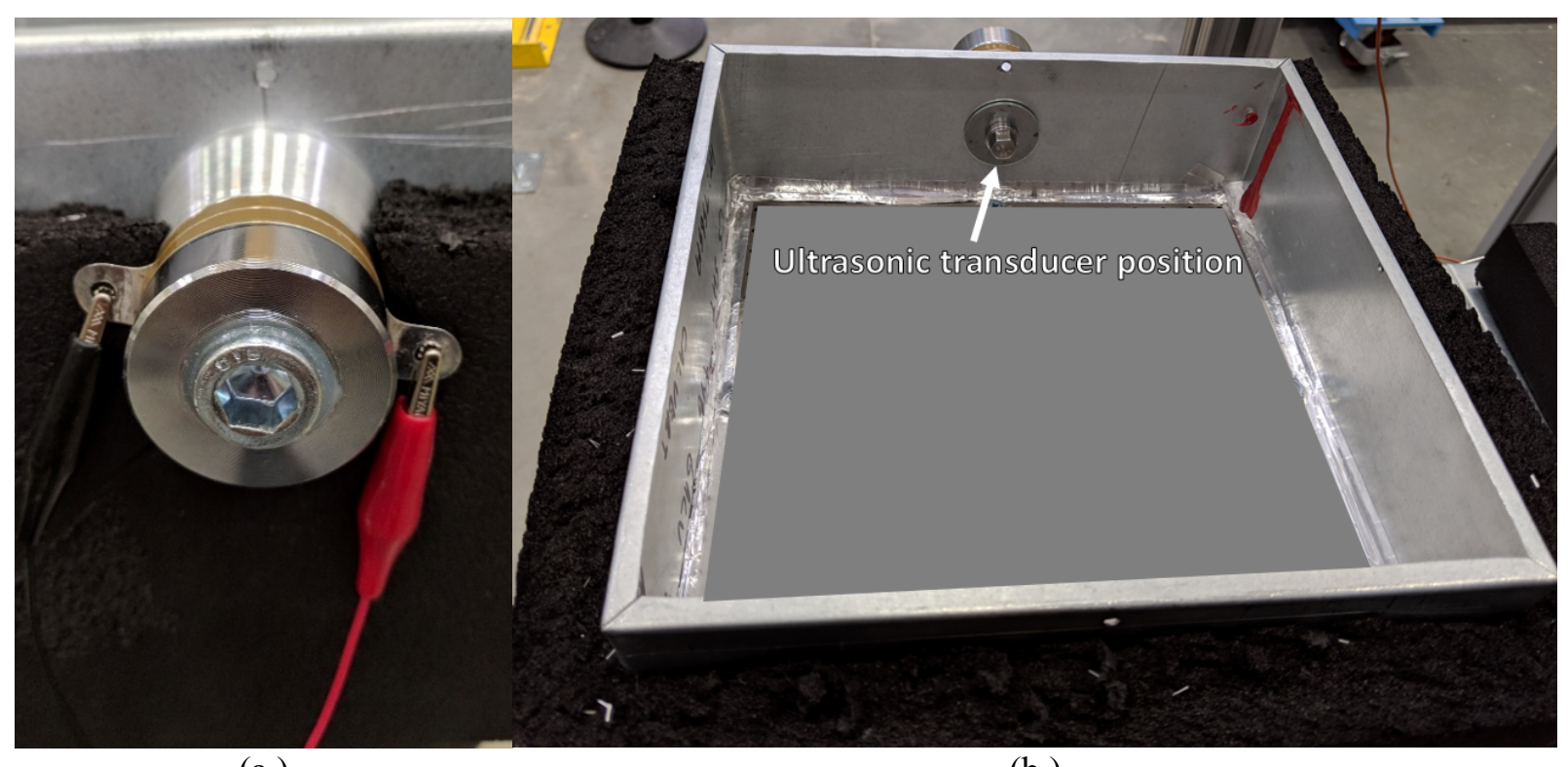

(a.)

(b.)

Figure 7. (a.) Bolt-clamped Langevin transducer attached to side wall of oven test section and (b.) position of transducer on inside wall of oven test section (perforated plate is intentionally covered for proprietary reasons)

A commercially available precision power amplifier was used to generate the high-frequency oscillating sine wave signal. It produced up to $600 \mathrm{~W}$ of RF Power over a frequency range of $10 \mathrm{kHz}$ to $6 \mathrm{MHz}$. The front panel allowed for control and display of the frequency and forward power (FP). The front panel also displayed the reflected and load power (RP and LP, respectively) readings. In the RF domain, load power represents the true power delivered to the load. It is the difference between the forward and reflected power. A non-zero reflected power results from a mismatch between the input impedance of the electrical load and output impedance of the corresponding signal source. Therefore, it is important to ascertain the load power, since it is a measure of the energy consumed by the load.

\subsubsection{SENSORS AND DATA ACQUISITION (DAQ)}

\subsubsection{DAQ hardware}

The main sensors used in the experimental setup consisted of thermocouples, pressure transducers and a scale. Table 2 lists the data acquisition (DAQ) hardware from National Instruments (NI) that was used to acquire data from the sensors. It consisted of a module for thermocouple measurement (NI-9214) and one for voltage measurement (NI-9209). The thermocouple module directly measured the $\mathrm{mV}$ output from the thermocouples and had built-in cold junction compensation. The NI software converted the $\mathrm{mV}$ values into ${ }^{\circ} \mathrm{C}$. The voltage module measured the voltage output from the pressure transducers and scaling equations from their calibration were used to convert voltage to physical pressure measurement. It was not necessary to use the DAQ for measurement of the scale output; these values were read directly from the scale display and manually recorded. 
Table 2. Data acquisition hardware

\begin{tabular}{|l|c|l|}
\hline Chassis or module & \multicolumn{1}{|c|}{ Function } & \multicolumn{1}{c|}{ Specifications } \\
\hline cDAQ-9171 & \multicolumn{1}{|c|}{ Chassis } & $\begin{array}{l}\text { 1-Slot, USB CompactDAQ } \\
\text { Chassis }\end{array}$ \\
\hline NI-9214 & Analog input - temperature & $\begin{array}{l} \pm 78 \text { mV, Isothermal C Series } \\
\text { Temperature Input Module }\end{array}$ \\
\hline NI-9209 & Analog input - voltage & $\begin{array}{l} \pm 10 \mathrm{~V}, 500 \mathrm{~S} / \mathrm{s}, \text { 16-Channel C } \\
\text { Series Voltage Input Module }\end{array}$ \\
\hline
\end{tabular}

\subsubsection{DAQ software}

National Instruments LabVIEW software was used to interface with the hardware, acquire data from sensors and save it to a file. A screenshot of the LabVIEW Virtual Instrument (VI) is shown in during operation. The VI also converted raw measurements into physical quantities and displayed them in real time on the front panel in numeric outputs and graphs. This included scaled temperatures (in ${ }^{\circ} \mathrm{C}$ and ${ }^{\circ} \mathrm{F}$ ), static pressure (in inWC) and air flow rate (in $\mathrm{ft}^{3} / \mathrm{min}$ or CFM). The VI sample rate was $1 \mathrm{~Hz}$ and all data were displayed on the front panel and recorded at this rate. 


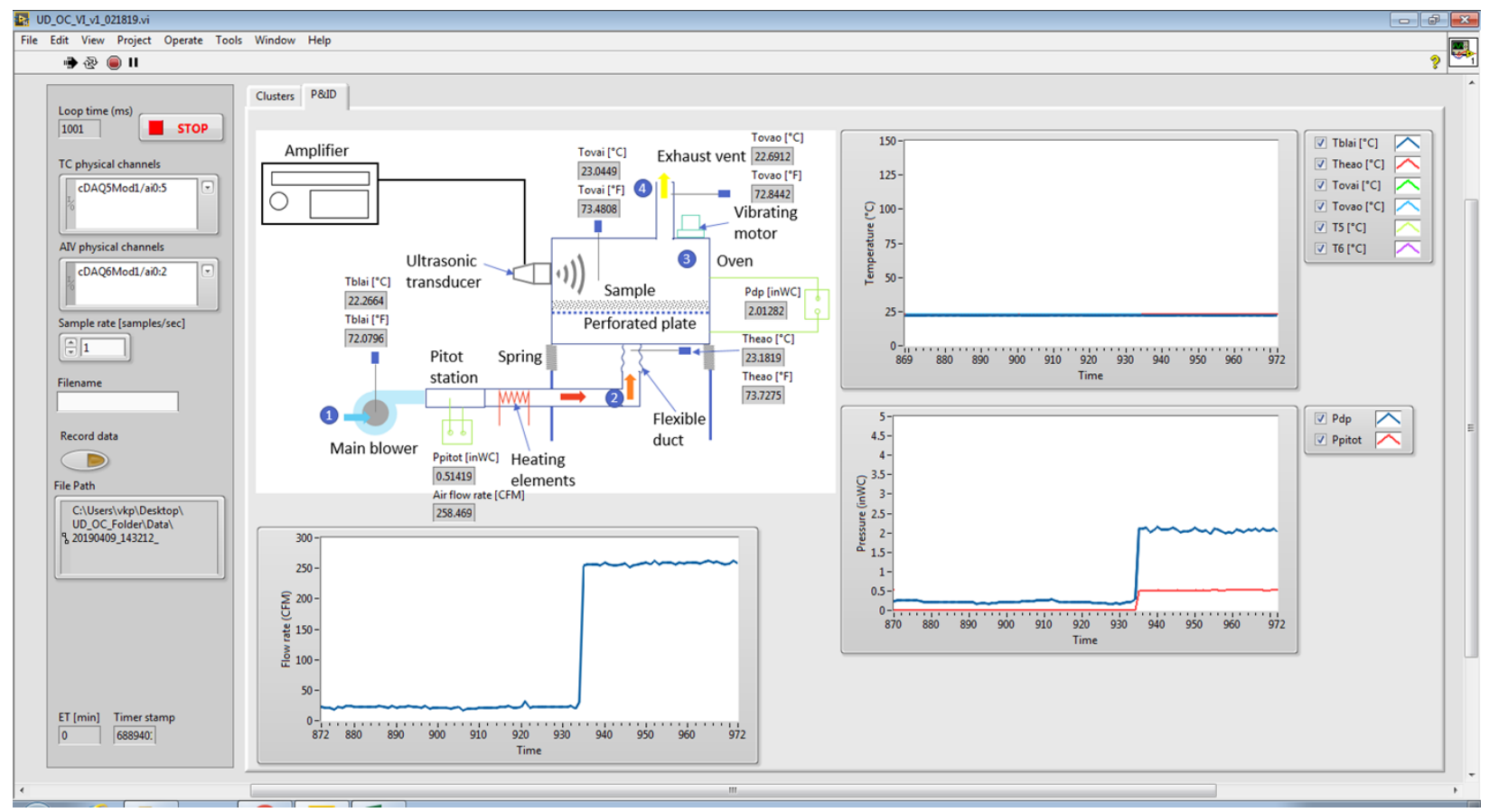

Figure 8. Screenshot of NI LabVIEW VI front panel display

\subsubsection{Other sensors}

Temperature sensors: Omega type-T thermocouple probes (TMQSS-062U-6) were used for all temperature measurements. The probes were 6 " long and 0.0625 " in diameter, with ungrounded, stainless-steel sheaths. The maximum measurement uncertainty was $\pm 0.5^{\circ} \mathrm{C}$.

Pressure transducers: For the static pressure measurement, a Setra Model 264 Low Differential Pressure Transducer was used. The measurement range was $0-25$ " in. $\mathrm{H} 2 \mathrm{O}$, with a $0-5 \mathrm{~V}$ DC analog output and accuracy of $\pm 1 \%$ of the full-scale range. For the pitot station pressure measurement, an Omega Model PX655-01DI Differential Pressure Transducer was used. The measurement range was $0-1$ " in. $\mathrm{H} 2 \mathrm{O}$, with a $4-20 \mathrm{~mA}$ analog output and accuracy of $\pm 0.25 \%$ of the full-scale range.

Air flow rate measurement: For the air flow measurement, an Aluminum LO-flow pitot traverse station from Air Monitor Corporation was used along with the above-mentioned differential pressure transducer. The accuracy of the pitot station was $\pm 2 \%$. The outer diameter of the station was 4 " and the range of measurement was $35-400 \mathrm{CFM}$. The station consisted of a honeycomb flow straightener-equalizer section and several total pressure sensor holes. To determine the air flow rate, the air velocity in $\mathrm{ft} / \mathrm{min}$ (or FPM) was first determined using Eq. (1). Next, the air velocity was simply multiplied by the station area $\left(0.09 \mathrm{ft}^{2}\right)$ to get the air flow rate in $\mathrm{ft}^{3} / \mathrm{min}$ or CFM in Eq. (2). Note that the factor of 4005 in Eq. (1) accounts for the density of air at standard conditions and unit conversions.

$$
\begin{aligned}
& \text { Air velocity }=4005 \times \sqrt{\text { Velocity pressure }} \\
& \text { Air flow rate }=\text { air velocity } \times \text { station area }
\end{aligned}
$$

Power measurement: Various methods were used for power measurement. For the blower and ultrasonic amplifier, plug-in Watt-meters were used, with the average power consumption read directly from the display and manually recorded. For the heater power consumption, separate measurements of applied 
voltage and current were made using a multimeter, to calculate the individual heater power, as shown in Table 3.

Table 3. Measured values of heater applied voltage and current

\begin{tabular}{|l|c|c|c|}
\hline Heater & Voltage [V] & Current [A] & Calculated power [W] \\
\hline Heater 1 & 208.3 & 19.3 & 4020 \\
\hline Heater 2 & 208.0 & 19.4 & 4035 \\
\hline
\end{tabular}

Mass measurement: A Sartorius Midrics MW1P1U-30ED-L scale was used for all mass measurements. The scale had a maximum capacity of $30 \mathrm{~kg}$ and readability of 150,000 divisions, or $\pm 0.2 \mathrm{~g}$. The base of the scale had dimensions of $400 \times 300 \mathrm{~mm}$.

\subsubsection{COMPLETED EXPERIMENTAL SETUP}

Figure 9 shows the completed experimental setup once all components were assembled and ready for experiments.

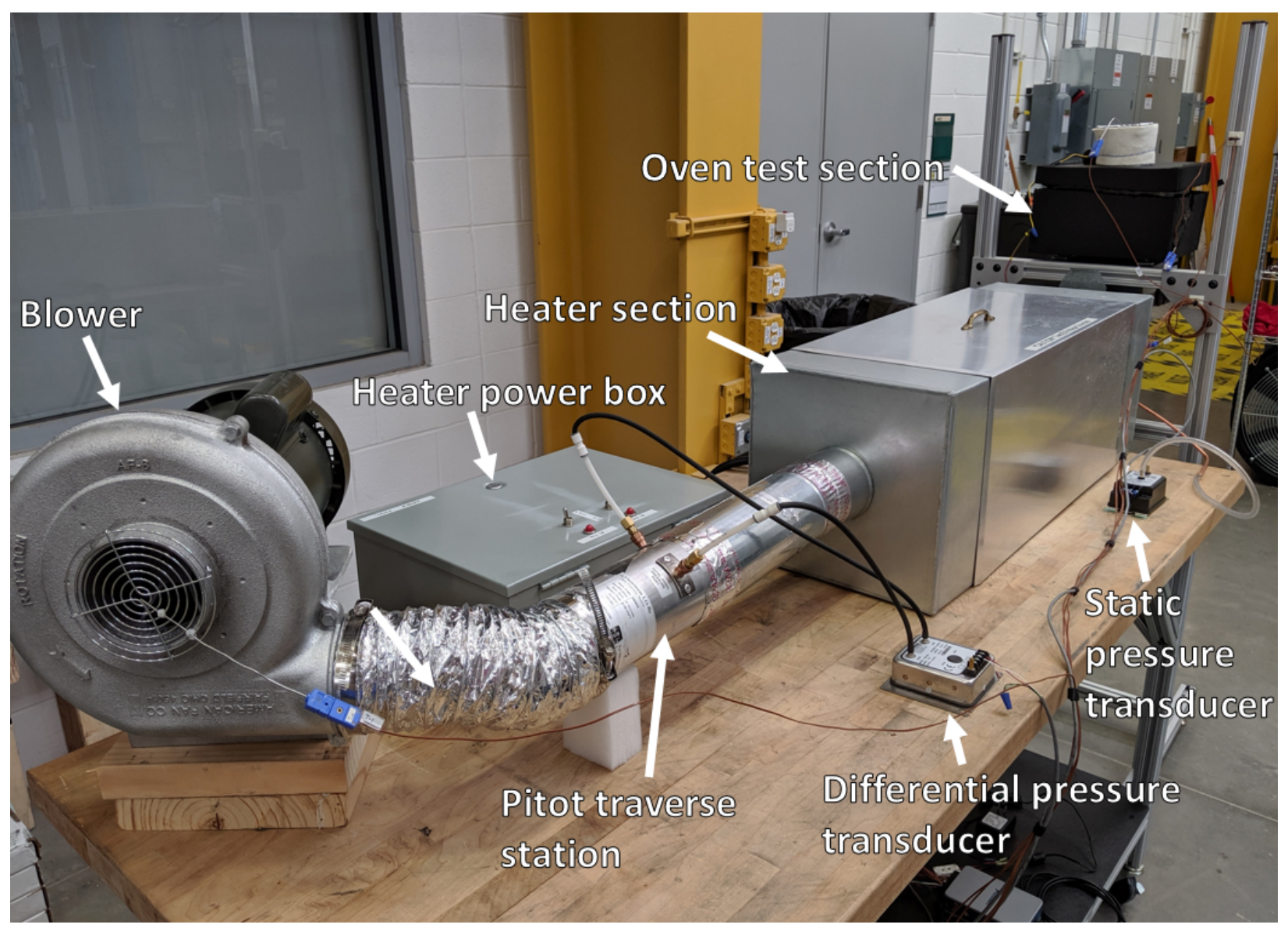

Figure 9. Completed experimental setup 


\subsection{EXPERIMENTAL MATRIX AND RESULTS}

\subsubsection{SHAKEDOWN TESTING}

Before the experimental setup was completed, shakedown tests were performed on the system to ensure that the temperature, pressure and flow requirements could be met. To determine the achievable air temperatures for a given oven cross-sectional area (to size the oven), the procedure outlined in Section 4.1.5 was followed. The test setup for this process is shown in Figure 10. It consisted of duct transitions with various cross-sectional areas which were attached to the perforated plate. In Figure 10, air flows out of the heater section, through the transition duct pieces and out through the perforated plate section on the right. Thermocouples are installed at the outlet of the heater section and after the perforated plate.

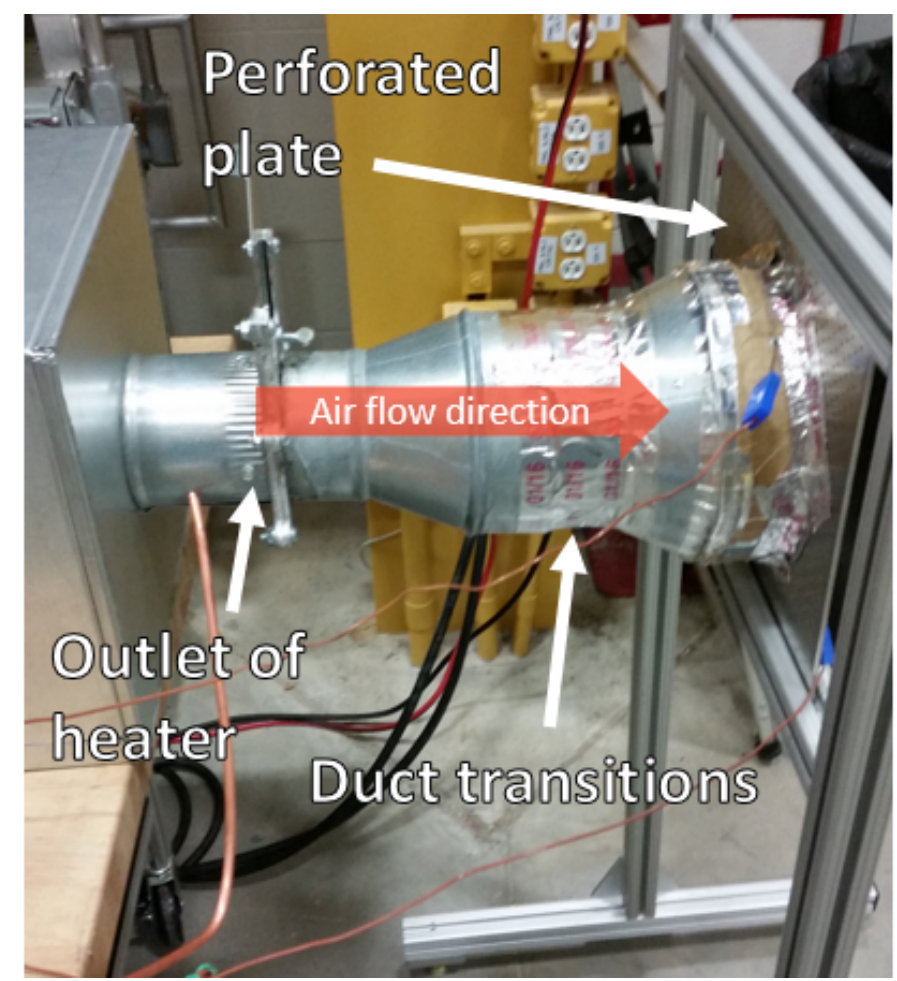

Figure 10. Test stand for shakedown testing of different duct diameters with perforated plate

Based on the procedure, tests were conducted for three different cross-sectional areas. The measurements of temperature, air flow rate and static pressure at the heater exit (i.e. before the perforated plate) for all three areas are shown in Figure 11 and Figure 12. All quantities were non-dimensionalized by their corresponding target values for proprietary reasons. For example, a value of 1 for the non-dimensional temperature at the perforated screen outlet meant the target temperature was reached. Similarly, a nondimensional air flow rate of 1 meant the target air flow rate was reached. By using the data in Figures Figure 11 and Figure 12, the oven test section was sized. 


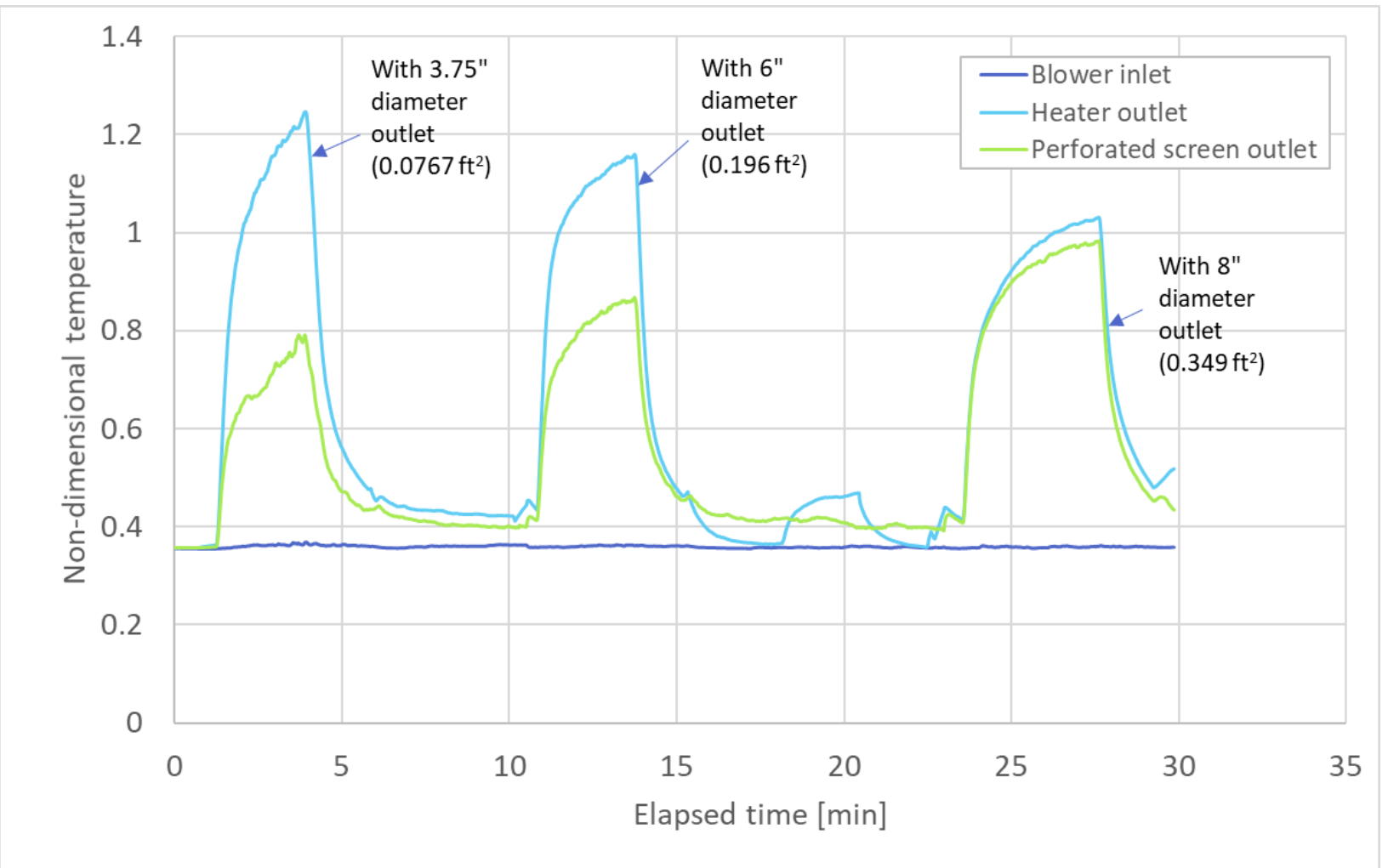

Figure 11. Shakedown test results with different duct diameter outlets - temperatures at inlet, heater outlet and perforated screen outlet

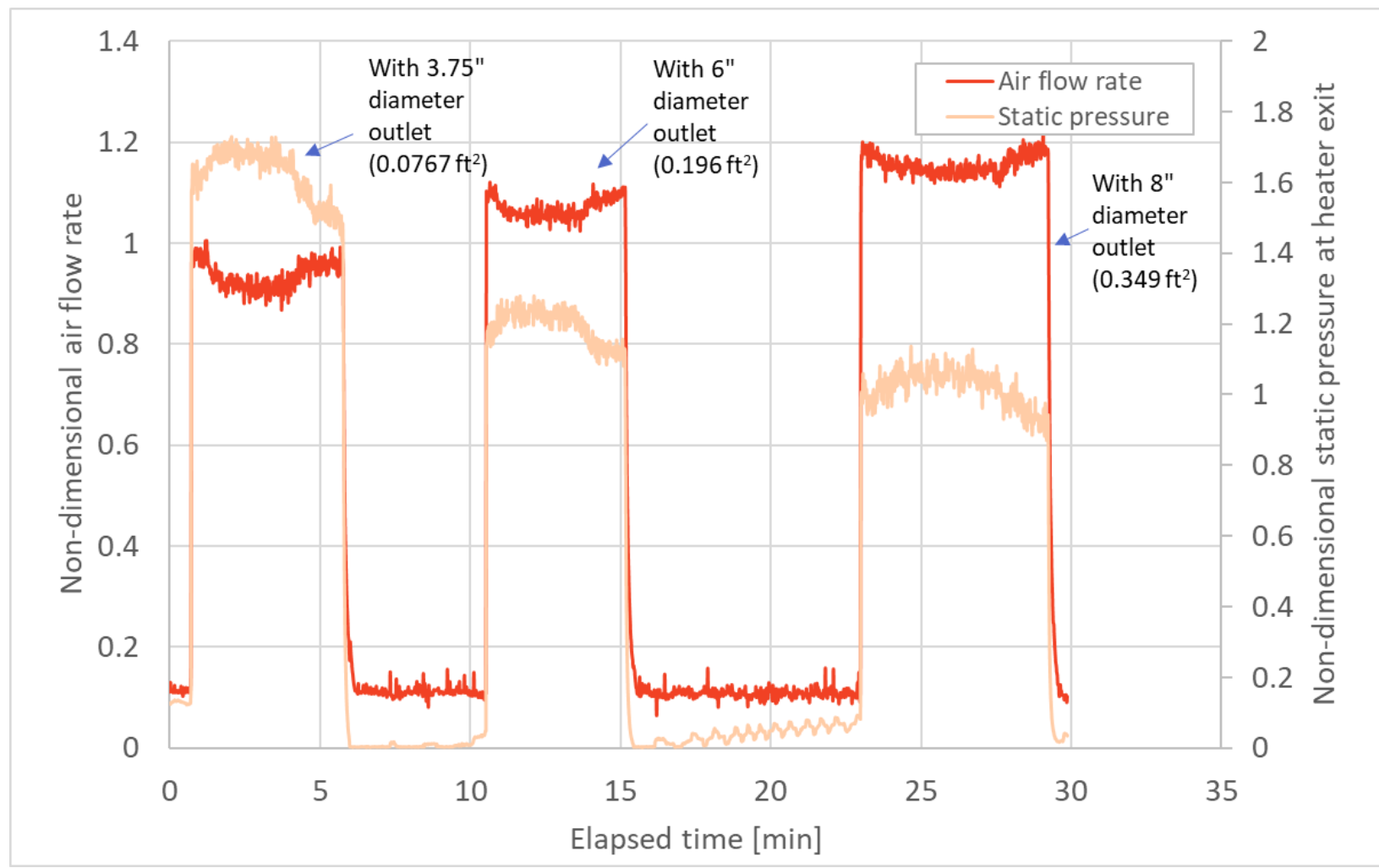

Figure 12. Shakedown test results with different duct diameter outlets - air flow rate and static pressure 


\subsubsection{PROPOSED EXPERIMENT MATRIX AND PROCEDURE}

To determine the effect of non-contact ultrasonic vibration on the drying of the dry-use fiberglass material, an initial experiment matrix was developed, as shown in Table 4 . The only parameters to be varied were the drying time and ultrasonic power.

Table 4. Initial proposed experiment matrix

\begin{tabular}{|c|c|c|c|c|c|c|}
\hline \multirow{2}{*}{$\begin{array}{c}\text { Experiment } \\
\text { number }\end{array}$} & \multicolumn{3}{|c|}{ Drying time [min] } & \multicolumn{3}{|c|}{ Ultrasonic power [W] } \\
\hline & Short & Medium & Long & No power & Intermediate & Maximum \\
\hline 1 & $x$ & & & $x$ & & \\
\hline 2 & & $\times$ & & $\times$ & & \\
\hline 3 & & & $x$ & $x$ & & \\
\hline 4 & $x$ & & & & $x$ & \\
\hline 5 & & $x$ & & & $x$ & \\
\hline 6 & & & $\times$ & & $\times$ & \\
\hline 7 & $x$ & & & & & $x$ \\
\hline 8 & & $x$ & & & & $x$ \\
\hline 9 & & & $\times$ & & & $\times$ \\
\hline
\end{tabular}

However, after initial shakedown testing of the fiberglass material, the heater power and initial test sample mass were added as parameters. Although the number of parameters were increased, the full factorial set of experiments were not conducted, as not all conditions were expected to provide useful information. The procedure for a typical experiment with the ultrasonic transducer activated was as follows:

1. Weigh wet test sample (supplied by Owens Corning at specified moisture content).

2. Turn on blower and heaters (one or both heaters were activated, depending on the experiment matrix).

3. Wait 2-3 min for oven components to heat up and reach steady state temperatures.

4. Turn off heaters and blower momentarily.

5. Open oven test section lid and load wet test sample into oven on top of perforated plate

6. Close oven test section lid and do the following simultaneously or in quick succession:

a. Re-activate blowers and heaters

b. Start timer

c. Turn on ultrasonic transducer (depending on the experiment matrix)

7. Allow drying process to proceed for $\mathrm{X}$ min (depending on the experiment matrix).

8. Turn off ultrasonic transducer, heaters and blowers.

9. Open oven test section lid and remove dried test sample for weighing. 


\section{End of experiment.}

The quantities that were recorded for each experiment included the average heater power, average blower power, average ultrasonic amplifier power, actual ultrasonic load power, initial test sample mass, final test sample mass, drying time, temperature vs. time at various locations, air flow rate vs. time and static pressure at oven inlet vs. time.

\subsubsection{EXPERIMENTAL RESULTS AND DISCUSSION}

The overall experimental results are summarized in Table 5 below. As before, the data has been nondimensionalized wherever appropriate using non-dimensional parameters for proprietary reasons. The parameters varied during each experiment and their possible values are listed below:

1. Average heater power $-0 \%, 50 \%$ or $100 \%$ of maximum heater output.

2. Actual ultrasonic load power - No power, intermediate power or maximum power possible for the selected ultrasonic transducer.

3. Initial test sample mass - pre-defined nominal test sample mass and double test sample mass

4. Drying time $-50 \%, 100 \%, 200 \%, 300 \%$ and $400 \%$ of pre-defined nominal drying time

Certain experiments which had the same operating parameters are highlighted and the corresponding key is given at the bottom of Table 5. The important measurements given in Table 5 are:

1. Test sample mass difference - the difference between the initial and final test sample mass as a percentage of the initial test sample mass.

2. The total energy consumption - the total energy consumed by the heaters, blower and ultrasonic amplifier over the duration of the experiment.

3. Drying effectiveness - the amount of water removed from the test sample per unit energy consumption for the duration of the drying experiment (the higher the drying effectiveness, the more efficient the process was).

Note: The total energy consumption had units of $\mathrm{kWh}$ and the drying effectiveness had units of $\mathrm{kg}_{\text {water }}$ removed $/ \mathrm{kWh}$. Although the numerical values are represented with data bars, the results of the experiments can still be compared with one another. 
Table 5. Overall experimental results

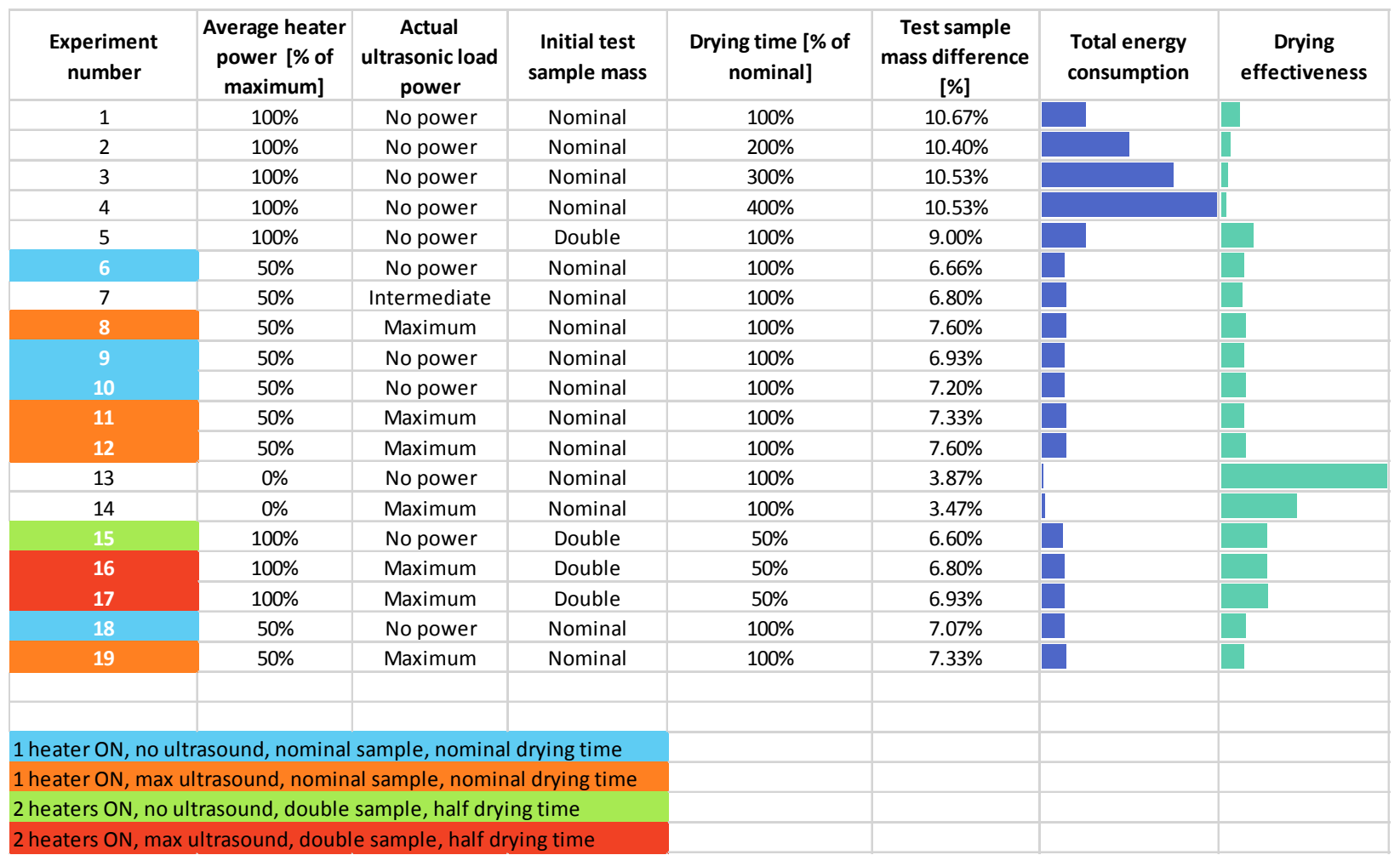

As shown above, experiments with drying times which were well above nominal (i.e. expts. 2, 3, and 4) resulted in the largest test sample mass difference between the beginning and end of the experiments, but also had the highest total energy consumption. As a result, they had poor drying effectiveness. Experiments in which the heaters were not activated at all (expts. 13 and 14) resulted in the highest drying effectiveness, since only the blowers and ultrasonic amplifier (for expt. 14) were consuming power. However, they also resulted in very little drying, as shown by the marginal differences in test sample mass that were recorded.

When we compare the experiments with no ultrasound (i.e. blue highlighted boxes: $6,9,10,18$ ) to identical experiments with the ultrasonic transducer active (i.e. orange highlighted boxes: 8, 11, 12, 19), there was an average increase of $7.21 \%$ in the test sample mass difference. Since all other parameters were kept the same for these experiments, this suggests that the ultrasonic transducer was responsible for enhanced drying. Considering that the design of the oven test section, ultrasonic transducer selection and placement are all far from optimum, this was a significant result.

Similarly, in the experiments where the heater power was increased and the initial test sample mass was doubled, the test sample mass difference for the cases with ultrasonic transducer active (red highlighted boxes: 16 and 17) was on average $4.04 \%$ higher than that of the no ultrasound case (green highlighted box: 15). This indicates that although the ultrasonic transducer was contributing to some enhancement in the drying process, other factors (such as the relationship between the oven size and test sample mass) likely also played an important role.

To calculate the potential energy savings that can be achieved with the above enhancements, the results were compared to the energy consumption for existing drying techniques. 


\section{SUBJECT INVENTIONS}

There are no subject inventions that arose from this work.

\section{COMMERCIALIZATION POSSIBILITIES}

This project was a unique contribution to the state-of-the-art and the proposed technology has potential to be a simple retrofit on the existing state-of-the art drying ovens. The system can be modulated and be used to control the drying rate and improve the final quality of the dry products. There is also potential for cost savings as the non-contact ultrasonic drying technology could reduce energy use in the Dry-Use fiberglass drying process and increase the production rate. Energy reduction and increased productivity would result in cost savings. This can have added benefits of reduced greenhouse gas (GHG) emission due to decreased energy use and reduced process energy use. Based on all this, a detailed cost-benefit analysis will be necessary before a commercialization decision can be made.

\section{PLANS FOR FUTURE COLLABORATION}

The possibility of future collaboration is being determined, based on the initial experimental results of the study.

\section{CONCLUSIONS}

In this project, a benchtop fluidized bed oven setup was successfully fabricated at ORNL to experimentally study the effect of non-contact ultrasonic vibration on traditional convective hot air drying. Conditions similar to large scale drying ovens were achieved in the benchtop experimental setup and a parametric study was conducted to dry fiberglass samples provided by Owens Corning. The parameters that were varied included the heater power, ultrasonic power, initial test sample mass and drying time. The experimental results showed that up to $7.21 \%$ enhancement in the water removal rate was possible due to non-contact ultrasonic vibration. These results are very encouraging since the design of the fluidized bed oven and ultrasonic transducer selection and design have not been optimized. This indicates that further improvements in the drying effectiveness of drying fiberglass products may be possible using non-contact ultrasonic vibration. In addition to energy efficiency performance, an analysis of the expected costs and payback period for implementing this technology is necessary before a commercialization decision can be made. 